\section{(A) Check for updates}

Cite this: Dalton Trans., 2019, 48 8106

Received 29th March 2019, Accepted 17th April 2019

DOI: 10.1039/c9dt01352k

rsc.li/dalton

\title{
Stereoisomers and functional groups in oxidorhenium(v) complexes: effects on catalytic activity $\dagger$
}

\author{
J. A. Schachner, (D)* B. Berner, F. Belaj (D) and N. C. Mösch-Zanetti (D)*
}

The syntheses of oxidorhenium(v) complexes $\left[\operatorname{ReOCl}(\mathbf{L} \mathbf{a}-\mathbf{c})_{2}\right](3 a-c)$, equipped with the bidentate, mono-anionic phenol-dimethyloxazoline ligands HL1a-c are described. Ligands HL1b-c contain functional groups on the phenol ring, compared to parent ligand 2-(4,4-dimethyl-4,5-dihydro-1,3-oxazol-2$\mathrm{yl}$ )-phenol H1a; namely a methoxy group ortho to the hydroxyl position (2-(4,4-dimethyl-4,5-dihydro1,3-oxazol-2-yl)-6-methoxyphenol, H1b), or a nitro group para to the hydroxyl position (2-(4,4-dimethyl4,5-dihydro-1,3-oxazol-2-yl)-4-nitrophenol, $\mathrm{H} 1 \mathrm{c})$. Furthermore, oxidorhenate(v) complexes $\left(\mathrm{NBu}_{4}\right)$ $\left[\mathrm{ReOCl}_{3}(\mathbf{L} \mathbf{a} \mathbf{a}-\mathbf{b})\right](\mathbf{2} \mathbf{a}-\mathbf{b})$ were synthesized for solid state structural comparisons to $\mathbf{3 a}-\mathbf{b}$. All novel complexes are fully characterized including NMR, IR and UV-Vis spectroscopy, MS spectrometry, X-ray crystallography, elemental analysis as well as cyclic voltammetry. The influence of functional groups $(R=-H$, $-\mathrm{OMe}$ and $-\mathrm{NO}_{2}$ ) on the catalytic activity of $3 \mathrm{a}-\mathrm{c}$ was investigated in two benchmark catalytic reactions, namely cyclooctene epoxidation and perchlorate reduction. In addition, the previously described oxidorhenium(v) complex $\left[\mathrm{ReOCl}(\mathbf{o z})_{2}\right](4)$, employing the phenol-oxazoline ligand 2-(4,5-dihydro-2-oxazolyl) phenol Hoz, was included in these catalysis studies. Complex $\mathbf{4}$ is a rare case in oxidorhenium(v) chemistry where two stereoisomers could be separated and fully characterized. With respect to the position of the oxazoline nitrogen atoms on the rhenium atom, these two stereoisomers are referred to as $\mathrm{N}, \mathrm{N}$-cis and $\mathrm{N}, \mathrm{N}$-trans isomer. A potential correlation between spectroscopic and structural data to catalytic activity was evaluated.

\section{Introduction}

The interest in the chemistry of high oxidation state rhenium oxides was certainly triggered by the two seminal publication on methyltrioxorhenium(VII) (MTO) by Herrmann in $1991 .{ }^{1}$ After finding an elegant synthesis of MTO, the group of Herrmann and others demonstrated the impressive catalytic activities in oxidation catalysis by MTO, including catalytic epoxidation of a wide variety of olefins. ${ }^{2,3-5}$ To this day, MTO remains the most active rhenium-based epoxidation catalyst, reaching turnover numbers (TONs) of $>20000 .^{3,6,7}$ However, MTO suffered from epoxide hydrolysis, when acid-sensitive epoxides are formed. ${ }^{8}$ This observed drawback, as well as decomposition reactions of MTO, prompted the investigation of oxidorhenium(v) complexes as potential epoxidation cata-

Institute of Chemistry, University of Graz, Schubertstr. 1, 8010 Graz, Austria. E-mail: joerg.schachner@uni-graz.at

$\dagger$ Electronic supplementary information (ESI) available: Details on synthesis of ligand H1c as well as crystallographic data of complexes $\mathbf{2 a - b}$ and $\mathbf{3 a - c . ~ C C D C}$ 1895410, 1850856 and 1562677-1562679. For ESI and crystallographic data in CIF or other electronic format see DOI: $10.1039 / \mathrm{c} 9 \mathrm{dt} 01352 \mathrm{k}$ lysts. The first two examples of such rhenium(v) complexes again came from the group of Herrmann, using tetra- and bidentate Schiff-base ligands. ${ }^{9,10}$ Over the last few years the chemistry of oxidorhenium(v) complexes and their application in homogeneous catalytic epoxidation of cyclooctene further developed. ${ }^{6,11-18}$ Compared to the impressive activities of MTO however, oxidorhenium(v) complexes had been inferior epoxidation catalysts, with the published complexes until 2014 only reaching turnovers of TON $<75 .{ }^{17}$ Our initial research efforts concentrated on phenol-pyrazole (HpyzR) ligands, equipped with various substituents $\mathrm{R}\left(\mathrm{R}=\mathrm{H}, \mathrm{Me}, \mathrm{OMe}, \mathrm{Br}, \mathrm{NO}_{2}\right)$ on the phenol moiety (Fig. 1). ${ }^{14,16}$

The introduction of functional groups on the phenol moiety was found to have a beneficial effect on epoxidation activity of the resulting oxidorhenium(v) complexes [ReOCl $\left.(\text { pyzR })_{2}\right] \cdot{ }^{14}$ Especially the set of complexes with $\mathrm{R}=\mathrm{OMe}, \mathrm{Br}$ and $\mathrm{NO}_{2}$ showed enhanced activities $(\mathrm{TON}>95)$ in the epoxidation of cyclooctene ( $1 \mathrm{~mol} \%$ cat. loading, 3 equiv. TBHP) as well as activity with the green oxidant $\mathrm{H}_{2} \mathrm{O}_{2}$ (TONs between 55 to 61$).{ }^{14}$ In contrast, complexes $\left[\mathrm{ReOCl}(\text { pyzR })_{2}\right.$ ] with $\mathrm{R}=\mathrm{H}$ and Me showed either reduced epoxidation activity (TON $<60$, with TBHP) or none at all (TON $=0$, with $\mathrm{H}_{2} \mathrm{O}_{2}$ ) under the same con- 


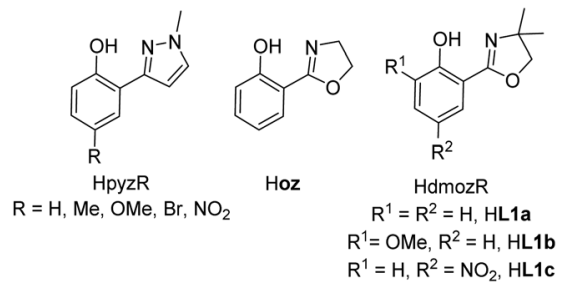

Fig. 1 Phenol-pyrazole and phenol-oxazoline $\mathrm{ON}$-bidentate ligands used in oxidorhenium(v) chemistry, shown with their commonly used abbreviations.

ditions. ${ }^{14}$ Whereas MTO and related oxidorhenium(VII) complexes were shown to form side-on coordinated mono-peroxo and bis-peroxo complexes as the active catalyst, ${ }^{4,5,18,19}$ no such structures have been observed or isolated for oxidorhenium(v) complexes like 3a-c. A peroxide activation mechanism via deprotonation of the incoming peroxide similar to dioxidomolybdenum(vi) complexes ${ }^{20}$ seems less likely for oxidorhenium(v) complexes. Here, the oxido ligand is much less nucleophilic due to strong $\pi$-bonding. ${ }^{21}$

A second type of catalytic reaction effected by an oxidorhenium(v) complex was first described in 2000. The group of Abu-Omar reported the capability of complex $\left[\operatorname{ReOCl}(\mathbf{o z})_{2}\right](4)$, equipped with the phenol-oxazoline ligand Hoz (Fig. 1), to catalytically reduce perchlorate anions to chloride. ${ }^{22-24}$ We also became interested in this remarkable chemistry of the Hoz ligand, and began to investigate the oxazoline-dimethyl version of the Hoz ligand, the Hdmoz ligand (HL1a, Fig. 1), in perchlorate reduction chemistry. ${ }^{12}$ Based on the ground laying work of the Abu-Omar group, a dissociative oxygen atom transfer (OAT) mechanism of redox-catalysis was postulated, with the Re atom cycling between Re(v) and Re(VII) (Scheme 1). ${ }^{22-25}$

In perchlorate reduction catalysis, we could show that isomers play an important role for catalyst activity. ${ }^{11,12}$ For an octahedral complex with two ON-bidentate and two monodentate ligands like $\mathbf{3 a - c}$, six stereoisomers could form in principle (Scheme 2). Isomers A and B have a trans arrangement of the oxido and $\mathrm{X}$ ligand, with the bidentate ON-ligand in the

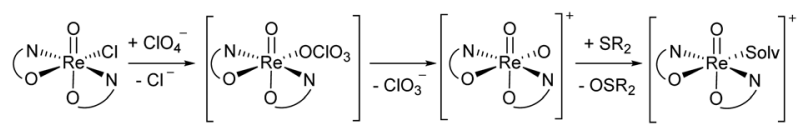

Scheme 1 Proposed dissociative oxygen atom transfer mechanism of perchlorate reduction via $\operatorname{Re}(\mathrm{v}) /(\mathrm{VII})$ redox catalysis; solv = solvent.

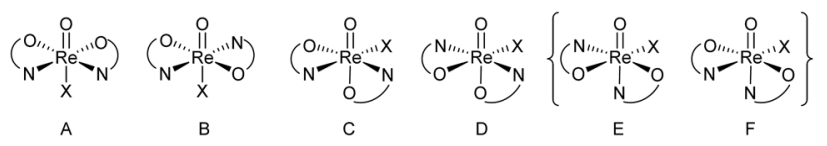

Scheme 2 Possible stereoisomers A-F for octahedral [ReOX $\left.(\mathrm{ON})_{2}\right]$ complexes ( $\mathrm{E}$ and $\mathrm{F}$ have not been observed yet). equatorial plane. Both isomers contain an element of symmetry $\left(\sigma\right.$ or $\left.C_{2}\right)$ and are therefore also referred to as "symmetric isomers". Depending on the relative position of the nitrogen donor atom, isomer $\mathrm{A}$ is referred to as an $\mathrm{N}, \mathrm{N}$-cis isomer, B as an $\mathrm{N}, \mathrm{N}$-trans isomer. In isomers $\mathrm{C}$ to $\mathrm{F}$, ligands $\mathrm{O}$ and $\mathrm{X}$ adopt a mutual cis orientation to each other, resulting in total loss of symmetry. Most of the isolated oxidorhenium(v) complexes belong to asymmetric isomers $\mathrm{C}$ and $\mathrm{D} .{ }^{17}$ Again $\mathrm{C}$ constitutes an $N, N$-cis and $\mathrm{D}$ an $N, N$-trans isomer. Isomers $\mathrm{E}$ and $\mathrm{F}$ have not been observed yet in rhenium chemistry. This might be due to the strong trans influence of the oxido ligand, making the coordination of the neutral nitrogen donor in this position unlikely.

For parent complex $\left[\mathrm{ReOCl}(\mathbf{o z})_{2}\right]$ 4, both the $N, N-c i s$ (C, cis4) and $N, N$-trans (D, trans-4) isomer are formed in the synthesis (Scheme 4). It could be shown that trans-4 is more active in perchlorate reduction compared to $c i s-4 .{ }^{12}$ The initial step of the catalytic cycle is loss of the chlorido ligand, creating a vacant site on the rhenium atom. In cis-4, the neutral nitrogen atom of the oxazoline moiety is trans to the chlorido ligand, exerting a weaker trans-influence compared to trans-4, where the phenolate oxygen atom is trans to the chlorido ligand (Scheme 2). This situation elongates the Re-Cl bond in trans-4 (2.4093(10) ̊̊), compared to cis-4 (2.383(3) ̊). ${ }^{12}$ Hence the loss of chlorido ligand requires less energy for trans-4. The same is true for the subsequent steps in the catalytic cycle. Those are OAT from the substrate to the rhenium atom and subsequent OAT from rhenium to the sulfide acceptor. For all these steps, the energy barriers are higher for cis-4 compared to trans $-\mathbf{4} .{ }^{12}$ In the synthesis of complexes $3 \mathbf{a}-\mathbf{c}$, special attention was paid on the potential formation of $N, N$-cis or $N, N$-trans isomers (Scheme 4), because of their significant influence on catalytic activity. ${ }^{12,22,26,27}$ Stereocontrol in the synthesis of oxidorhenium(v) complexes to obtain the desired $N, N$-trans isomer is therefore highly desired. In literature, it was shown that a single methyl group on the oxazoline moiety is sufficient for the isomerically pure formation of an $N, N$-trans isomer. ${ }^{26,27}$ The resulting steric hindrance in an hypothetical $\mathrm{N}, \mathrm{N}$-cis complex was identified as one source of stereo-control. ${ }^{27}$ The observation that complexes cis/trans-4, without a substituent on the oxazoline moiety, are obtained as a mixture of $\mathrm{N}, \mathrm{N}$-cis and $N, N$-trans isomers supports this conclusion. Within this manuscript we would like to present an additional element of stereocontrol, based on the coordination chemistry of the Hdmoz ligands HL1a-c.

With this manuscript, we would like to present results obtained for the set of oxidorhenium(v) complexes [ReOCl $\left.(\mathbf{L 1 a}-\mathbf{c})_{2}\right]$ in epoxidation and perchlorate reduction catalysis. By systematic introduction of electron-donating (-OMe, HL1b) and an electron-withdrawing $\left(-\mathrm{NO}_{2}, \mathrm{HL1c}\right)$ groups (Fig. 1) we are relating structural and spectroscopic factors to catalytic activity. In addition factors that control the stereoselectivity of the synthesis of these complexes were investigated with the help of model complexes 2a-b. Finally the influence of stereoisomerism on catalytic epoxidation activity was tested with complexes cis- and trans-4. 


\section{Results and discussion}

\section{Synthetic procedures}

Ligands H1a-b were synthesized according to literature, ${ }^{12,28,29}$ HL1c based on established literature procedures ${ }^{30}$ with modifications (see ESI $\dagger$ ). Anionic oxidorhenate(v) complexes $\left(\mathrm{NBu}_{4}\right)$ $\left[\mathrm{ReOCl}_{3}(\mathbf{L 1 a}-\mathbf{b})\right] \mathbf{2 a}-\mathbf{b}$ were obtained by reaction of precursor complex $\left(\mathrm{NBu}_{4}\right)\left[\mathrm{ReOCl}_{4}\right]$ with one equivalent of ligand HL1a or HL1b at room temperature in EtOH (Scheme 3). Only this precursor, together with short reaction times $(0.5-1 \mathrm{~h})$ at room temperature, allows for isolation of mono-ligated complexes 2a-b. Under the same reaction conditions, precursor $\left[\mathrm{ReOCl}_{3}\left(\mathrm{OPPh}_{3}\right)\left(\mathrm{SMe}_{2}\right)\right]$ gives mixtures with bis-ligated complexes $\mathbf{3} \mathbf{a}$ and $\mathbf{3 b}$, respectively.

Complexes $\left[\operatorname{ReOCl}(\mathbf{L 1 a}-\mathbf{c})_{2}\right]$ 3a-c were obtained by reaction of precursor complex $\left[\mathrm{ReOCl}_{3}\left(\mathrm{OPPh}_{3}\right)\left(\mathrm{SMe}_{2}\right)\right]$ with two equivalent of ligands HL1a-c respectively, under refluxing conditions in $\mathrm{CH}_{3} \mathrm{CN}$ (Scheme 4). Complete dissolution of the poorly soluble precursor complex as well as a typical color change of the reaction mixtures to green (3a and $\mathbf{3 c}$ ) or greenish-brown (3b) indicate successful synthesis of the respective complexes. The isolated complexes are stable to air and moisture, and are in general insoluble in non-polar solvents like pentane or heptane. Based on their substituents on the phenol moiety, complex 3b (-OMe) shows the highest solubility in polar solvents like $\mathrm{CH}_{2} \mathrm{Cl}_{2}, \mathrm{CHCl}_{3}$, or $\mathrm{CH}_{3} \mathrm{CN}$, followed by $\mathbf{3 a}$ $(-\mathrm{H})$ and $3 \mathbf{c}\left(-\mathrm{NO}_{2}\right)$ with the lowest solubility. Also alcohols like $\mathrm{CH}_{3} \mathrm{OH}$ and EtOH or $\mathrm{CH}_{3} \mathrm{CN} / \mathrm{H}_{2} \mathrm{O}$ mixtures are possible solvents. When using the HdmozR ligands HL1a-c in the synthesis of complexes $3 \mathbf{a}-\mathbf{c},{ }^{1} \mathrm{H}$ NMR spectroscopy and solid state
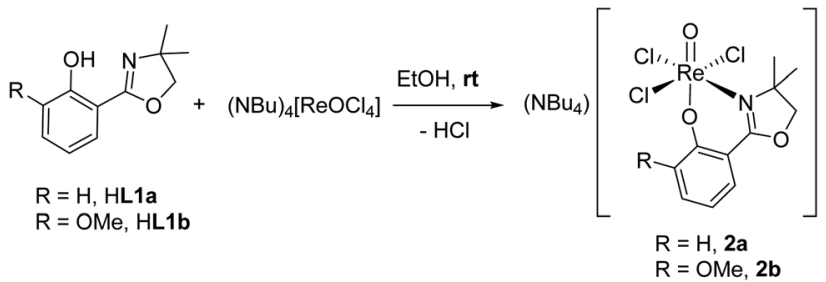

Scheme 3 Synthesis of $\left(\mathrm{NBu}_{4}\right)\left[\operatorname{ReOCl}_{3}(\mathrm{Lla}-\mathbf{b})\right] 2 \mathrm{a}-\mathbf{b}$.

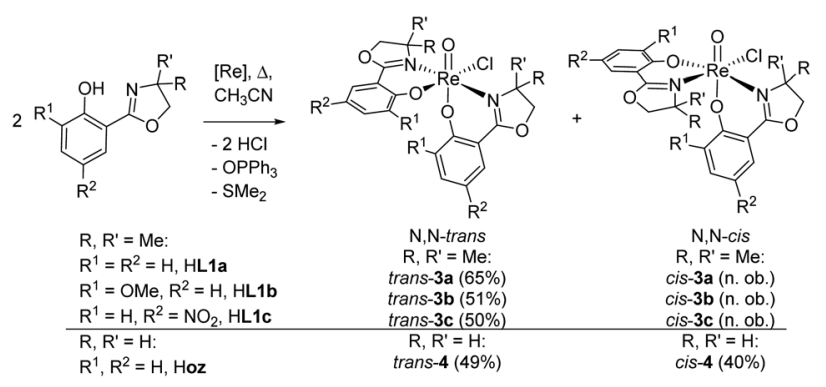

Scheme 4 Synthesis (isolated yield) of single isomer of trans-3a-c and isomeric mixture of complexes cis/trans-4 ([Re] $=\left[\mathrm{ReOCl}_{3}\left(\mathrm{OPPh}_{3}\right)\right.$ $\left.\left(\mathrm{SMe}_{2}\right)\right] ; \mathrm{n}$. ob. = not observed). structural data obtained by single-crystal X-ray analyses (Fig. 3) confirmed the exclusive formation of $N, N$-trans isomers.

\section{Crystallography}

Single crystals for all five novel complexes $\mathbf{2 a - b}$ and $3 \mathbf{3} \mathbf{a}-\mathbf{c}$ were obtained, and their solid state structure could be solved by X-ray crystallography. The molecular structures of $\mathbf{2 a}$ and $\mathbf{2 b}$ revealed the expected anionic oxidorhenate(v) complexes with $\left(\mathrm{NBu}_{4}\right)^{+}$as counterion (Fig. 2). Both complexes adopt a slightly distorted octahedral conformation with similar bond lengths and angles (Table 1). The presence of the methoxy group in $\mathbf{2 b}$ does not result in a significantly different coordination around the rhenium atom, compared to 2 a. Several other anionic trihalo oxidorhenate(v) complexes have been structurally characterized and show the same coordination pattern. ${ }^{9,26,31-33}$ In all cases, the alkoxide oxygen of the ligand moiety coordinates trans to the oxido ligand, resulting in an axial-equatorial coordination of the bidentate ligand, with the three chlorido ligands in a meridional coordination. This preferred coordination might also explain the absence of isomers $\mathrm{E}$ and $\mathrm{F}$ (Scheme 2) in rhenium chemistry.

Single crystals of complex 3a were obtained from an EtOH solution at $8{ }^{\circ} \mathrm{C}$, of complex $\mathbf{3 b}$ from an EtOH/EtOAc mixture at room temperature, and of complex $3 \mathrm{c}$ from a saturated EtOH solution by slow evaporation at $8{ }^{\circ} \mathrm{C}$. X-ray diffraction analysis revealed quite similar solid state structures, with the rhenium centers in a distorted octahedral coordination. In all
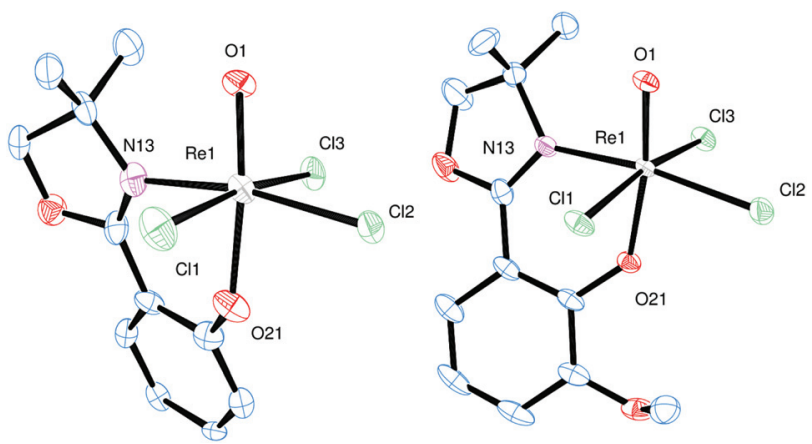

Fig. 2 Molecular views (50\% level) of $2 \mathrm{a}$ and $\mathbf{2 b}$ ( $\mathrm{H}$ atoms, solvent and $\left(\mathrm{NBu}_{4}\right)^{+}$molecules omitted for clarity).

Table 1 Selected bond lengths [Å] and angles $\left[^{\circ}\right]$ of $2 a-b$

\begin{tabular}{lll}
\hline$[\AA]$ & 2a & 2b \\
\hline Re1=O1 & $1.690(7)$ & $1.6801(16)$ \\
Re1-N13 & $2.172(8)$ & $2.1386(16)$ \\
Re1-O21 & $2.011(8)$ & $1.9800(16)$ \\
Re1-Cl1 & $2.381(3)$ & $2.3909(4)$ \\
Re1-Cl2 & $2.377(2)$ & $2.3717(4)$ \\
Re1-Cl3 & $2.420(3)$ & $2.3891(4)$ \\
\hline$\left.{ }^{\circ}\right]$ & & \\
\hline O1-Re1-O21 & & $171.18(9)$ \\
Cl1-Re1-Cl3 & $171.4(3)$ & $169.71(3)$ \\
N13-Re1-Cl2 & $171.51(10)$ & $171.40(6)$
\end{tabular}


cases the chlorido ligand is located cis to the oxido ligand. Furthermore, the $\mathrm{N}, \mathrm{N}$-trans orientation of the two bidendate ligands was confirmed for all three complexes (Fig. 3).

A summary of selected bond angles and distances for $\mathbf{3 a - c}$ can be found in Table 2. The observed bond lengths in com-
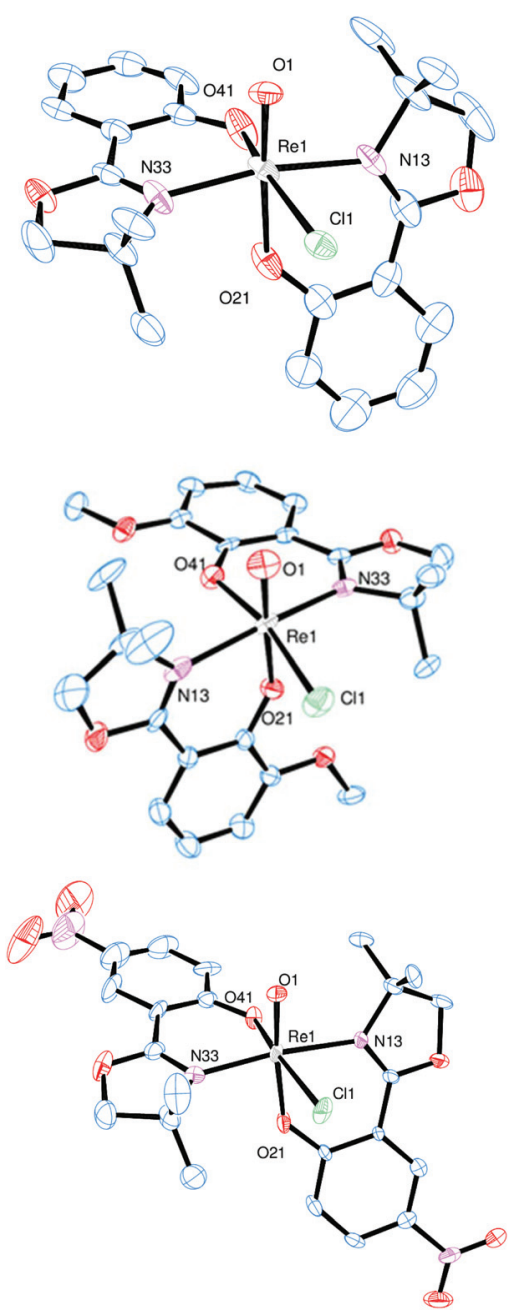

Fig. 3 Molecular views (50\% probability level) of complex 3a (top), 3b (middle) and 3c (bottom). Hydrogen atoms were omitted for clarity.

Table 2 Selected bond distances [Å] and angles $\left[^{\circ}\right]$ for complexes $3 a-c$

\begin{tabular}{llll}
\hline$[\AA]$ & 3a & 3b & 3c \\
\hline Re1=O1 & $1.682(6)$ & $1.757(4)$ & $1.719(4)$ \\
Re1-Cl1 & $2.440(2)$ & $2.400(2)$ & $2.4087(18)$ \\
Re1-N13 & $2.203(5)$ & $2.118(5)$ & $2.205(3)$ \\
Re1-N33 & $2.058(5)$ & $2.096(4)$ & $2.037(3)$ \\
Re1-O21 & $2.056(7)$ & $1.987(4)$ & $2.033(3)$ \\
Re1-O41 & $1.944(7)$ & $1.999(4)$ & $1.962(3)$ \\
\hline
\end{tabular}

\begin{tabular}{llll}
\hline [०] & & & \\
\hline O1-Re1-O21 & $173.2(3)$ & $177.3(3)$ & $172.91(17)$ \\
Cl1-Re1-O41 & $163.8(6)$ & $168.07(18)$ & $166.62(10)$ \\
N13-Re1-N33 & $165.9(2)$ & $165.4(3)$ & $168.63(13)$
\end{tabular}

plexes 3a-c show that the solid state structures are sensitive to the substituents on the ligand moieties L1a-c. However, a clear trend is not easily extracted from the data at hand. For example, 3a displays the longest Re-Cl1 distance, indicating a stronger trans influence of the L1a ligand moiety, compared to L1b-c. Also, complex 3a displays the shortest $\mathrm{Re}=\mathrm{O}$ bond, compared to complexes $\mathbf{3 b}-\mathbf{c}$, which show comparable $\mathrm{Re}=\mathrm{O}$ bond lengths, regardless of the electron-donating or -withdrawing nature of the phenol substituents. The rheniumoxido and rhenium-chlorido bond lengths in $\mathbf{3 c}$ are actually very similar to $\mathbf{3 b}$, equipped with the electron-donating ligand L1b.

\section{Stereo-control of isomers}

Switching from the $\mathrm{Hoz}$ to the $\mathrm{Hdmoz}$ ligand class, with two methyl groups on the oxazoline moiety, only leads to the respective $N, N$-trans complexes (Scheme 4). In order to study this stereoselective formation of $N, N$-trans isomers of $3 \mathbf{a}-\mathbf{c}$ in more detail, the two mono-ligated, anionic oxidorhenate(v) complexes $\left(\mathrm{NBu}_{4}\right)\left[\operatorname{ReOCl}_{3}(\mathbf{L 1 a})\right](\mathbf{2 a})$ and $\left(\mathrm{NBu}_{4}\right)\left[\operatorname{ReOCl}_{3}(\mathbf{L 1} \mathbf{b})\right]$ (2b) were synthesized (Scheme 3 ). The formation of monoligated complexes $\mathbf{2} \mathbf{a}-\mathbf{b}$ provides evidence that the synthesis of bis-ligated complexes $\left[\operatorname{ReOCl}(\mathbf{L 1 a}-\mathbf{c})_{2}\right]$ is a step-wise process. Thus, whether the $\mathrm{N}, \mathrm{N}$-trans or $\mathrm{N}, \mathrm{N}$-cis isomer is formed in the next step depends on the respective trans influence of the initially coordinated ligand moiety (Scheme 5).

Complex 2a can be compared to previously published complex $\left(\mathrm{H}_{2} \mathbf{O z}\right)\left[\operatorname{ReOCl}_{3}(\mathbf{o z})\right](\mathbf{2 - o z}){ }^{26}$ As mentioned above, the respective bis-ligated complex $\mathbf{3 a}$ is isomerically pure, whereas 4 is isolated as an isomeric $N, N$-trans and $N, N$-cis mixture. As summarized in Table 3, for complex 2a, the two trans coordinated chlorido ligands $\mathrm{Cl} 1$ and $\mathrm{Cl} 3$ exhibit longer bond distances to the Re center (2.381(3) and 2.420(3) A, respectively) compared to chlorido ligand $\mathrm{Cl} 2$, which is trans to the oxazoline nitrogen N13. Here the $\mathrm{Re}-\mathrm{Cl}$ bond distance is at

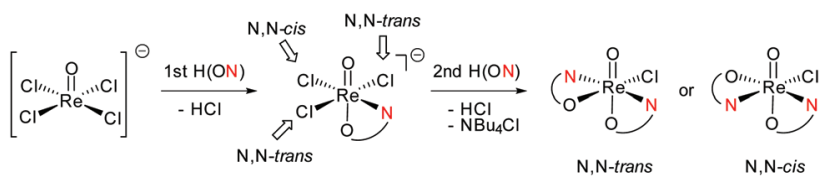

Scheme 5 Schematic representation of step-wise coordination of a bidentate ligand $\mathrm{H}(\mathrm{ON})(e . g$. $\mathrm{HL} 1 \mathrm{a}-\mathrm{c})$, with formation of $\mathrm{N}, \mathrm{N}$-trans or $\mathrm{N}, \mathrm{N}$-cis isomers. Arrows indicate point of substitution of incoming phenolate oxygen of the second $\mathrm{H}(\mathrm{ON})$ ligand and resulting stereoisomer.

Table 3 Comparison of $\mathrm{Re}-\mathrm{Cl}$ bond lengths $[\AA]]$ of $2-\mathrm{oz}, 2 \mathrm{a}$ and $2 \mathrm{~b}$

\begin{tabular}{|c|c|c|c|}
\hline & Re1-Cl1 & $\mathrm{Re} 1-\mathrm{Cl} 2$ & $\mathrm{Re} 1-\mathrm{Cl} 3$ \\
\hline $2 a$ & $2.381(3)$ & $2.377(2)$ & $2.420(3)$ \\
\hline $2 b$ & $2.3909(4)$ & $2.3717(4)$ & $2.3891(4)$ \\
\hline $2-o z^{26}$ & $2.4701(6)^{a}$ & $2.3690(6)$ & $2.3621(7)$ \\
\hline
\end{tabular}

${ }^{a}$ Elongated because of $\mathrm{H}$-bonding to neighboring $\left(\mathrm{H}_{2} \mathbf{o z}\right)^{+}$cations. 
2.377(2) A, as expected based on the weaker trans influence of N13. The same observations are made in case of $\mathbf{2} \mathbf{b}$, where bisligated complex $\mathbf{3 b}$ also only shows the $N, N$-trans isomer. Complex 2-oz displays an unusually long Re-Cl1 bond (2.4701(6) A), which is caused by two H-bonds to neighboring $\left(\mathrm{H}_{2} \mathbf{O z}\right)^{+}$cations in the unit cell. ${ }^{26}$ Therefore this bond has to be disregarded for the structural discussion. The remaining two

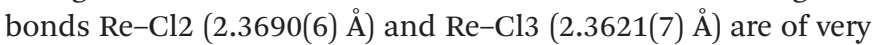
similar distances. Such a similar bonding situation could explain the observed mixtures of $\mathrm{N}, \mathrm{N}$-cis and $\mathrm{N}, \mathrm{N}$-trans isomers for 4 , as there is no preference for the point of coordination of the second incoming $\mathrm{Hoz}$ ligand (Scheme 5). The shorter and therefore stronger $\mathrm{Re}-\mathrm{Cl} 2$ bonds observed in $\mathbf{2 a}$ and $\mathbf{2 b}$ would explain the stereoselective synthesis of $\mathrm{N}, \mathrm{N}$-trans complexes $\mathbf{3 a - b}$.

\section{Cyclic voltammetry}

In order to evaluate the electronic situation on the Re center with respect to the ligand substituents, cyclic voltammetry experiments on bis-ligated complexes $\mathbf{3 a - c}$ were performed. In addition, also the two isomers of $N, N$-cis/trans 4 were investigated. Analyte solutions for cyclic voltammetry were near $1 \mathrm{mM}$ in acetonitrile, with $\left(\mathrm{NBu}_{4}\right) \mathrm{PF}_{6}$ used as supporting electrolyte $(0.1 \mathrm{M})$. The recorded currents $I_{\mathrm{p}}[\mu \mathrm{A}]$ were divided by the actual concentration of analyte to normalize the voltammograms for better comparability. All five complexes displayed quasi-reversible $\operatorname{Re}(\mathrm{v}) /(\mathrm{vi})$ redox couples at a positive potential, ${ }^{14,34}$ which also proved to be scan-rate independent. At negative potentials only irreversible redox events occurred. Half-wave potentials $E_{1 / 2}\left(E_{1 / 2}=\left(E_{\mathrm{p}, \mathrm{c}}+E_{\mathrm{p}, \mathrm{a}}\right) / 2\right)$ are given in Table 4 (referenced to ferrocene/ferrocenium).

For complexes 3a-c (Table 4 und Fig. 4), the half-wave potential of $3 \mathbf{c}$ is shifted by $280 \mathrm{mV}$ to higher potential, compared to unsubstituted $\mathbf{3 a}$, as expected for the electron-withdrawing nature of the nitro groups on the ligand moiety of L1c. Methoxy substituted complex $\mathbf{3 b}$ on the other hand is only shifted by $29 \mathrm{mV}$ to lower potential, compared to 3a, indicating a small electron-donating effect of the methoxy substituents in $\mathbf{3 b}$. The influence of the methyl groups on the oxazoline moiety can be compared between $\mathbf{3 a}$ and trans $\mathbf{- 4}$. Here, the $\operatorname{Re}(\mathrm{v}) /(\mathrm{vI})$ redox couple for trans $\mathbf{- 4}$ is $60 \mathrm{mV}$ lower than for 3a, indicating an electron-richer metal center in trans-4. The data in Table 4 and Fig. 4 show that the two stereoisomer of 4 have virtually identical redox potentials. Obviously, stereoisomerism does not have an effect on the redox potential of the Re center.

\section{Epoxidation of cyclooctene}

Complexes $\mathbf{2 a - b}, \mathbf{3 a - c}$ and cis/trans $\mathbf{- 4}$ were evaluated as catalysts in the epoxidation of standard substrate cyclooctene. The

Table 4 Redox potentials $E_{1 / 2}[\mathrm{~V}]$ of complexes $3 \mathrm{a}-\mathrm{c}$ and $\mathrm{N}, \mathrm{N}$-cis/trans 4 at $200 \mathrm{mV} \mathrm{s}^{-1}$ in $\mathrm{CH}_{3} \mathrm{CN}$

\begin{tabular}{llllll}
\hline$[\mathrm{V}]$ & $3 \mathrm{a}$ & $3 \mathbf{b}$ & 3c & cis-4 & trans -4 \\
\hline$E_{1 / 2}$ & 0.642 & 0.613 & 0.922 & 0.576 & 0.582
\end{tabular}
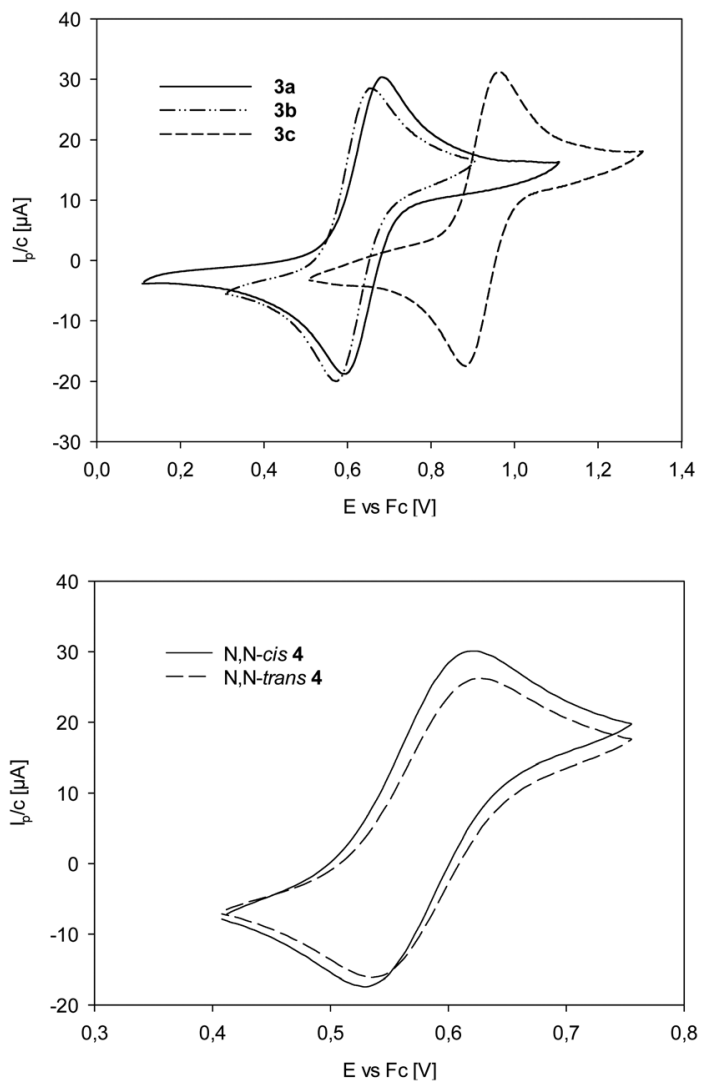

Fig. 4 Top: Comparison of $\operatorname{Re}(\mathrm{v}) / \operatorname{Re}(\mathrm{VI})$ redox couples of complexes 3a-c; bottom: comparison of $\operatorname{Re}(\mathrm{v}) / \operatorname{Re}(\mathrm{vl})$ redox couples of complexes cis/trans-4.

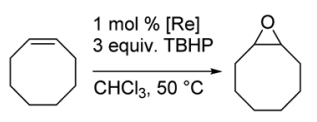

Scheme 6 Epoxidation of cyclooctene using tert-butylhydroperoxide (TBHP).

effect of the different isomers cis/trans-4 and the introduction of electron-donating (-OMe in $3 \mathbf{b})$ and withdrawing $\left(-\mathrm{NO}_{2}\right.$ in 3c) groups on catalytic activity was of particular interest. Complexes $\mathbf{2 a}$ and $\mathbf{2 b}$ were also tested for potential catalytic activity, as other mono-ligated complexes have proven to be active epoxidation catalysts. ${ }^{14,15}$ In typical catalytic experiments 3 equiv. of tert-butylhydroperoxide (TBHP) as oxidant with a 1 mol\% catalyst loading in $\mathrm{CHCl}_{3}$ at $50{ }^{\circ} \mathrm{C}$ and the substrate cyclooctene were used (Scheme 6). Reaction progress was monitored by withdrawing aliquots during the reaction and analysis with GC-MS. In general, all six tested complexes are catalytically active without induction period. A summary of turnover numbers (TON) with the respective turnover frequency (TOF $\left[\mathrm{h}^{-1}\right]$ ) is given in Table 5 . The lowest activity was displayed by complex $\mathbf{2 a}$, the highest by $\mathbf{3 c}$. Complexes $\mathbf{3 a}$ and 3b showed activities in a similar range as cis/trans-4. All complexes tested showed a significant brightening to complete dis- 
Table 5 TON (TOF $\left[\mathrm{h}^{-1}\right]$ ) for catalysts $2 \mathrm{a}-\mathrm{b}, 3 \mathrm{a}-\mathrm{c}$ and cis/trans -4

\begin{tabular}{ll}
\hline & TON (TOF) \\
\hline $\mathbf{2 a}$ & $<10$ \\
$\mathbf{2 b}$ & $23(0.96)$ \\
$\mathbf{3 a}$ & $37(1.5)$ \\
$\mathbf{3} \mathbf{b}^{a}$ & $34(1.4)$ \\
$\mathbf{3 c}$ & $80(9.4)$ \\
cis $\mathbf{- 4}$ & $40(1.7)$ \\
trans-4 & $30(1.3)$
\end{tabular}

TOFs $\left[\mathrm{h}^{-1}\right]$ were calculated at time of maximum yield of epoxide, not maximum activity of catalyst. If not mentioned otherwise, this was after $24 \mathrm{~h} .{ }^{a}$ Maximum yield of epoxide reached after $8.5 \mathrm{~h}$.

coloration from the initially green solutions during catalytic experiments, hinting at the formation of catalytically inactive $\operatorname{Re}\left(\right.$ VII) complexes. ${ }^{31}$

Time-conversion plots of cyclooctene epoxidation are given in Fig. 5.

Data in Fig. 5 and Table 5 show complexes $2 \mathbf{a}$ and $\mathbf{2 b}$ to exhibit the lowest activities (2a: TON $<10 ; 2 \mathbf{b}$ : TON $=23)$ of all seven investigated complexes. The few examples of oxidorhenate(v) complexes, that were also tested in epoxidation, were of similar low activity. ${ }^{31,33}$ Also the bis-ligated complexes 3a $($ TON $=37)$ and $\mathbf{3 b}($ TON $=34)$ showed low activities in the epoxidation of cyclooctene. In the cases of complexes $\mathbf{2} \mathbf{b}$ and 3b, significant discoloration after addition of oxidant TBHP could be observed, indicating a fast oxidation to unproductive perrhenate(vII) salts. ${ }^{31}$ Hence, ligand L1b seems to result in unstable complexes under strong oxidative conditions. This is quite in contrast to the OMe-substituted pyrazole-phenol complex $\left[\mathrm{ReOCl}(\mathrm{pyzOMe})_{2}\right]$, which showed excellent activities in cyclooctene epoxidation for both TBHP and $\mathrm{H}_{2} \mathrm{O}_{2} \cdot{ }^{14}$ A potential reason for the lack of activity for $\mathbf{2} \mathbf{b}$ and $\mathbf{3 b}$ could be ring-opening or decomposition reactions of the non-aromatic oxazoline moiety in $\mathbf{L 1} \mathbf{b}$, a known problem in oxazoline chemistry. ${ }^{24}$ In contrast to $\mathbf{3 b}$, complex $\mathbf{3 c}$, coordinated by the electron-withdrawing ligand moiety L1c, showed the highest

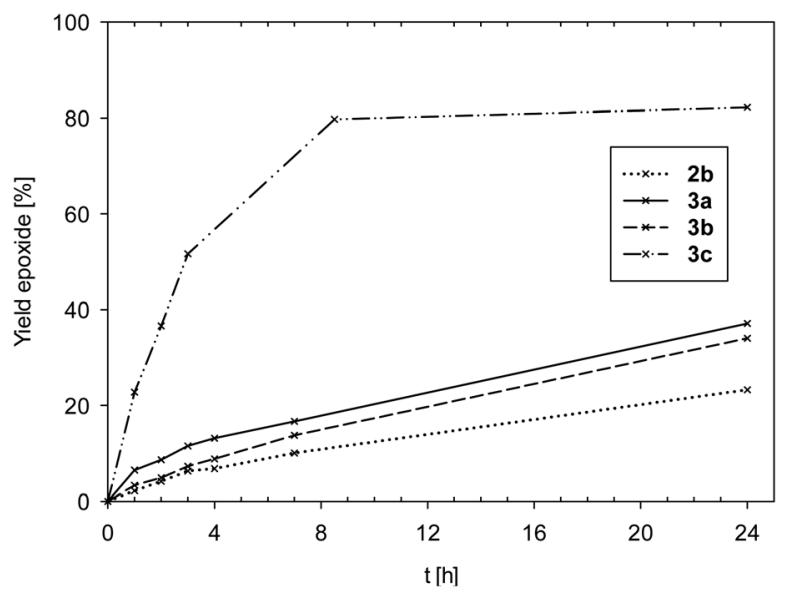

Fig. 5 Comparison of yield of epoxide for complexes $2 b$ and $3 a-c$ (2a is not shown due to low activity).

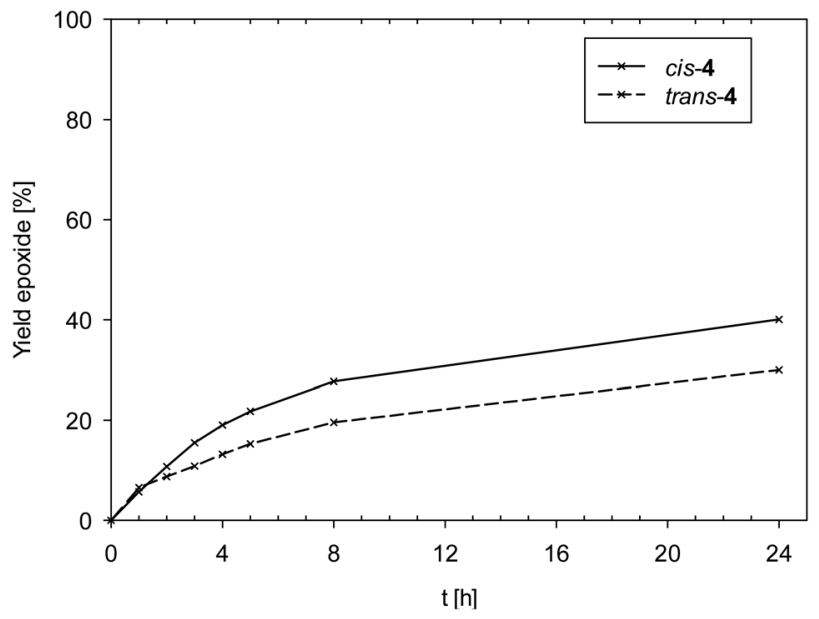

Fig. 6 Yield of epoxide for isomeric complexes cis/trans-4.

activity (TON $=80$ ) of all seven complexes (Fig. 5). In this case, the same positive effect on catalytic activity was observed as with $\left[\mathrm{ReOCl}\left(\mathrm{pyzNO}_{2}\right)_{2}\right] .{ }^{14}$ Obviously, the electron-withdrawing property of a nitro group results in enhanced epoxidation activity.

Data in Fig. 6 reveals a slight difference in catalytic performance of isomeric complexes cis- and trans-4, with cis-4 $(\mathrm{TON}=40)$ performing slightly better compared to trans $\mathbf{4}$ $(\mathrm{TON}=30)$.

With the results from epoxidation catalysis in hand, a potential correlation to structural and spectroscopic data can be probed. Table 6 shows a summary of such data together with TONs in cyclooctene epoxidation. By comparing spectroscopic data of complexes $\mathbf{3 a - c}$ and cis/trans-4 no obvious correlation however between electronic properties and catalyst activity can be drawn. ${ }^{12,22}$ Neither the $\mathrm{Re}=\mathrm{O}$ IR absorption frequency nor the $\mathrm{Re}=\mathrm{O}$ bond lengths show a clear trend correlating to epoxidation activity. For example, cis-4 and 3c show similar $\mathrm{Re}=\mathrm{O}$ IR absorptions (957 vs. $963 \mathrm{~cm}^{-1}$ ), but very different activities in epoxidation (TON 40 vs. 80). Similarly, the $\mathrm{Re}=\mathrm{O}$ bond distance of $3 \mathrm{c}$ does not vary considerably from the other $\operatorname{six} \mathrm{Re}=\mathrm{O}$ bond distances. Nevertheless, $3 \mathrm{c}$ is the most active epoxidation catalyst tested in this series. The

Table 6 Comparison of selected analytical and epoxidation data for complexes $2 \mathrm{a}-\mathrm{b}, 3 \mathrm{a}-\mathrm{c}$ and cis/trans-4

\begin{tabular}{lllllll}
\hline & $\begin{array}{l}\nu(\mathrm{C}=\mathrm{N}) \\
{\left[\mathrm{cm}^{-1}\right]}\end{array}$ & $\begin{array}{l}\nu(\mathrm{Re}=\mathrm{O}) \\
{\left[\mathrm{cm}^{-1}\right]}\end{array}$ & $\begin{array}{l}\lambda_{\max }(\varepsilon)^{a} \\
{[]}\end{array}$ & $\begin{array}{l}d(\mathrm{Re}=\mathrm{O}) \\
{[\AA]}\end{array}$ & $\begin{array}{l}E_{1 / 2}{ }^{b} \\
{[\mathrm{~V}]}\end{array}$ & $\begin{array}{l}\mathrm{TON}^{b} \\
{[}\end{array}$ \\
\hline $\mathbf{2 a}^{b}$ & 1611 & 962 & $710(73)$ & $1.690(7)$ & Irr. $^{c}$ & $<10$ \\
$\mathbf{2 b}^{b}$ & 1609 & 969 & $580(56)$ & $1.6801(16)$ & Irr. $^{c}$ & 23 \\
$\mathbf{3 a}$ & 1604 & 955 & $635(69)^{b}$ & $1.682(6)$ & 0.642 & 37 \\
$\mathbf{3 b}^{b}$ & 1582 & 955 & $660(65)$ & $1.757(4)$ & 0.613 & 34 \\
$\mathbf{3 c}^{b}$ & 1588 & 963 & $670(85)$ & $1.719(4)$ & 0.922 & 80 \\
trans-4 $^{22}$ & 1630 & 972 & $665(87)$ & $1.693(2)$ & 0.582 & 30 \\
cis-4 $^{12}$ & 1620 & 957 & $650(69)$ & $1.689(8)$ & 0.576 & 40
\end{tabular}

${ }^{a}$ In $\mathrm{CH}_{2} \mathrm{Cl}_{2}, \varepsilon=$ molar extinction coefficient $\left[\mathrm{dm}^{-3} \mathrm{~mol}^{-1} \mathrm{~cm}^{-1}\right] \cdot{ }^{b}$ This work. ${ }^{c}$ Only irreversible redox waves observed. 
only property of $\mathbf{3 c}$ that is significantly different compared to the other six complexes is the measured redox potential $E_{1 / 2}$ of $0.922 \mathrm{~V}$. This seems to indicate a more active catalyst if an electron poor rhenium center is present. The similarly active catalyst $\left[\mathrm{ReOCl}\left(\mathrm{pyzNO}_{2}\right)_{2}\right]$ also showed a similar high redox potential $E_{1 / 2}$ of $0.992 \mathrm{mV}^{14}$

To summarize, stereoisomers as in cis/trans-4 do not play a significant role in epoxidation activity. The observed differences in electronic and steric properties are most likely too small to cause a significant difference in catalytic activity. Electron-withdrawing substituents seem to have a beneficial effect on epoxidation, as both $\left[\mathrm{ReOCl}\left(\mathrm{dmozNO}_{2}\right)_{2}\right] 3 \mathbf{c}$ as well as the previously published complex $\left[\operatorname{ReOCl}\left(\operatorname{pyzNO}_{2}\right)_{2}\right]$ showed enhanced catalytic activity. ${ }^{14}$ These results indicate that an electron-deficient rhenium center results in higher catalyst activity and must therefore facilitate the oxygen atom transfer from TBHP to the olefin. The exact mode of interaction between the rhenium center and TBHP remains unclear at this point. The redox potential $E_{1 / 2}$ might have predictive power concerning catalyst activity.

\section{Perchlorate reduction}

Complexes $\mathbf{2 a - b}, \mathbf{3 a}-\mathbf{c}$ and cis/trans-4 were tested in the challenging reduction of perchlorate to chloride, with a $3.2 \mathrm{~mol} \%$ catalyst loading in the presence of four equivalents of the sulfide acceptor $\mathrm{SMe}_{2}$ (DMS) (Scheme 7). Reactions were conducted in $\mathrm{CD}_{3} \mathrm{CN} / \mathrm{D}_{2} \mathrm{O}$ mixtures of $95 / 5$ or $50 / 50$ vol\%, and the conversion of $\mathrm{SMe}_{2}$ to $\mathrm{OSMe}_{2}$ (DMSO) was monitored by ${ }^{1} \mathrm{H}$ NMR spectroscopy over $24 \mathrm{~h}$. Whereas the $95 / 5 \mathrm{vol} \%$ mixture is necessary to fully dissolve the $\mathrm{LiClO}_{4}$ substrate, we were interested if higher water contents in the reaction affect catalyst activity. This could either occur by potential hydrolytic decomposition of the catalyst or coordination of the $\mathrm{H}_{2} \mathrm{O}$ molecule to the vacant site on the rhenium thereby inhibiting catalysis. From reaction of 4 with AgOTf $\left(\mathrm{OTf}=\mathrm{SO}_{2} \mathrm{CF}_{3}{ }^{-}\right)$it is known that $\mathrm{H}_{2} \mathrm{O}$ will coordinate to the resulting cationic oxidorhenium(v) triflate complex. The solid state structure of complex $\left[\mathrm{ReO}(\mathbf{o z})_{2}\left(\mathrm{H}_{2} \mathrm{O}\right)\right] \mathrm{OTf}$ revealed the formation of a symmetric $N, N$-trans stereoisomer (isomer B, Scheme 7), with the water oxygen atom coordinated trans to the oxido ligand and the oz ligands in equatorial position. ${ }^{23}$ From DFT calculations it was shown that a symmetric cation B is not catalytically active in perchlorate reduction, as the coordination site trans to the oxido ligand is deactivated for perchlorate coordination. ${ }^{12}$ The catalytically active species therefore should remain an isomer $\mathrm{D}$ (Scheme 7), with the vacant coordination site cis to the oxido ligand.

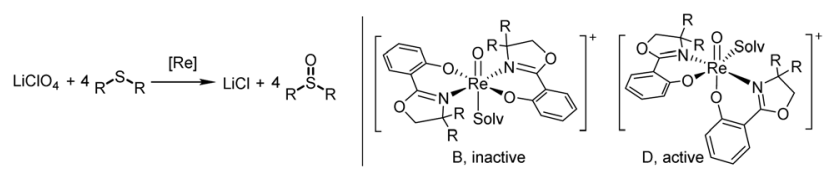

Scheme 7 Left: catalytic perchlorate reduction by oxidorhenium(v) complexes; right: catalytically inactive and active stereoisomers in perchlorate reduction; solv $=$ solvent .
Table 7 Yield of DMSO [\%] from catalytic perchlorate reduction after $24 \mathrm{~h}$

\begin{tabular}{lcc}
\hline DMSO [\%] & 5 vol\% $\mathrm{D}_{2} \mathrm{O}$ & 50 vol $\% \mathrm{D}_{2} \mathrm{O}$ \\
\hline 2a-b & 0 & 0 \\
3a & 75 & 32 \\
3b & 78 & 64 \\
3c & $48^{a}$ & $0^{b}$ \\
cis-4 & 33 & 58 \\
trans-4 & $>99^{22}$ & 91
\end{tabular}

Conditions: $3.2 \mathrm{~mol} \%$ catalyst, 4 equiv. of DMS, $\mathrm{CD}_{3} \mathrm{CN} / \mathrm{D}_{2} \mathrm{O}, 25{ }^{\circ} \mathrm{C}$. ${ }^{a}$ Only partly soluble. ${ }^{b}$ Insoluble.

Results are summarized in Table 7. While mono-ligated rhenate complexes $\mathbf{2 a - b}$ are not active, complexes $\mathbf{3 a}-\mathbf{c}$ and cis/ trans-4 were capable to reduce perchlorate at both water contents (5 and $50 \mathrm{vol} \%$ ), with the exception of nitro-substituted complex 3c. Complex 3c showed complete loss of catalytic activity at $50 \mathrm{vol} \%$ water. In this case however, we attribute this to the low solubility of $3 \mathbf{c}$ in aqueous media. In both solvent mixtures, solid 3c can be observed throughout the $24 \mathrm{~h}$ experiment time. Similar to our previous findings in 5 vol\% water, ${ }^{12}$ trans $\mathbf{4}$ remains the more active complex also at 50 vol\% water (91\%), compared to cis-4 (58\%). It is interesting to observe though that only for cis-4 the catalytic activity increases with increasing water content (33\% at 5 vol\% vs. $58 \%$ at $50 \mathrm{vol} \%$ ). At 5 vol\% water, $\mathbf{3 a}$ and $\mathbf{3 b}$ show essentially the same catalytic activity (75 and $78 \%$ respectively, Table 7 ). At 50 vol\% water however, 3a shows a significantly decreased activity (75 vs. $32 \%$ ). With $\mathbf{3 b}$, the difference is not as pronounced (78 vs. $64 \%)$.

For all active complexes, catalyst decomposition can be observed by ${ }^{1} \mathrm{H}$ NMR spectroscopy, as more and more free ligand is visible over the $24 \mathrm{~h}$ reaction time. A discoloration of the initially green solutions points to decomposition to perrhenate. ${ }^{31}$ The inactivity of complexes $2 \mathbf{a}-\mathbf{b}$ is consistent to previously tested, neutral mono-ligated complexes. ${ }^{12}$ The observed differences in catalytic activity in regard to water content are subject to current investigations in our lab.

\section{Conclusions}

Oxidorhenium(v) complexes equipped with phenol-dimethloxazoline ligands remain as a unique class of complexes capable to both catalytically epoxidize cyclooctene and reduce the challenging substrate perchlorate to harmless chloride under mild, aqueous conditions. In olefin epoxidation, stereoisomers do not play a significant role in catalyst activity, as demonstrated by the very similar TONs of cis/trans-4 (40/30). Electron withdrawing substituents rather seem to result in more active catalysts. Nitro-substituted complex $\mathbf{3 c}$ showed the highest activity with a TON of 80 for cyclooctene. This is line with the nitrosubstituted complex $\left[\mathrm{ReOCl}\left(\mathrm{pyzNO}_{2}\right)_{2}\right]$, which also proved to be a similarly active epoxidation catalyst. ${ }^{14}$ From comparison of spectral and structural data, it seems the redox potential 
$E_{1 / 2}$ obtained from cyclic voltammetry measurements correlates with enhanced activity in epoxidation, in contrast to IR absorptions or bond lengths.

In contrast to epoxidation catalysis, stereoisomers play a vital role for catalyst activity in perchlorate reduction. Here, only $\mathrm{N}, \mathrm{N}$-trans isomers are active. The formation of such $\mathrm{N}, \mathrm{N}$ trans isomers is a unique feature of the oxazoline ligand moiety. All related pyrazole based complexes $\left[\operatorname{ReOCl}(\text { pyzR })_{2}\right]$ adopted the $\mathrm{N}, \mathrm{N}$-cis conformation in the solid state, which also explains their inactivity in perchlorate reduction catalysis. ${ }^{16}$ For the observed stereoselective synthesis of complexes 3a-c, a novel mechanism is proposed, based on the two-step coordination of the respective HL1a-c ligands. Coordination of the first ligand gives intermediate oxidorhenate(v) complexes $\left[\mathrm{ReOCl}_{3}(\mathbf{L 1 a}-\mathbf{c})\right]^{-}$, with a strengthened $\mathrm{Re}-\mathrm{Cl} 2$ bond thereby directing the second incoming ligand to form an $\mathrm{N}, \mathrm{N}$ trans complex. Finally, $\mathrm{H}_{2} \mathrm{O}$ seems to play a far more important role in perchlorate catalysis than simply dissolving the perchlorate salt. It potentially can also act as an inhibitor by competing with substrate for the vacant coordination site on rhenium and favoring the formation of inactive cationic stereoisomers. Complexes $\mathbf{3 a}$ and $\mathbf{3} \mathbf{b}$ showed a diminished activity at 50 vol\% $\mathrm{H}_{2} \mathrm{O}$ compared to 5 vol\%, whereas conversion to DMSO actually increased for less active stereoisomer cis-4. The exact role of $\mathrm{H}_{2} \mathrm{O}$ however is subject to ongoing investigations in our lab.

\section{Experimental section}

\section{General}

The rhenium precursors $\left[\mathrm{ReOCl}_{3}\left(\mathrm{OPPh}_{3}\right)\left(\mathrm{SMe}_{2}\right)\right]^{35}$ and $\left(\mathrm{NBu}_{4}\right)\left[\mathrm{ReOCl}_{4}\right]^{36}$ were prepared according to previously published methods. The ligands $\mathrm{HL1a}^{27,29} \mathbf{H L 1 b}^{28}$ as well as complexes $\mathbf{3 \mathbf { a } ^ { 1 2 }}$ and cis/trans $\mathbf{4}^{\mathbf{1 2}}$ were prepared via published routes. Synthesis of HL1c can be found in the ESI. $\dagger$ Chemicals were purchased from commercial sources and used without further purification. NMR spectra were recorded with a Bruker Avance $(300 \mathrm{MHz})$ instrument. Chemical shifts are given in ppm and are referenced to residual protons in the solvent. Coupling constants $(J)$ are given in Hertz $(\mathrm{Hz})$. Mass spectra were recorded with an Agilent 5973 MSD - Direct Probe using the EI ionization technique. Samples for infrared spectroscopy were measured on a Bruker Optics ALPHA FT-IR Spectrometer equipped with an ATR diamond probe head. GC-MS measurements were performed on an Agilent 7890 A with an Agilent 19091J-433 column coupled to a mass spectrometer type Agilent 5975 C. Electrochemical measurements were performed under an inert $\mathrm{N}_{2}$ atmosphere in a glove box in dry acetonitrile (stored over molecular sieve) with a Gamry Instruments Reference 600 Potentiostat using a three electrode setup. Platin was used as working electrode, Pt wire (99.99\%) as supporting electrode; the reference electrode was a $\mathrm{Ag}$ wire immersed in a solution of $0.01 \mathrm{M} \mathrm{AgNO}_{3}$ and $0.1 \mathrm{M}\left(\mathrm{NBu}_{4}\right) \mathrm{PF}_{6}$ in $\mathrm{CH}_{3} \mathrm{CN}$ separated from the solution by a Vycor ${ }^{\circledR}$ tip. Supporting electrolyte used was $\left(\mathrm{NBu}_{4}\right) \mathrm{PF}_{6}(0.1 \mathrm{M})$. Elemental analyses were carried out using a Heraeus Vario Elementar automatic analyzer at the University of Technology Graz.

\section{$\mathrm{X}$-ray structure determinations}

Crystallographic data (excluding structure factors) for $2 a$, $\mathbf{2 b}, \mathbf{3 a}, \mathbf{3 b}$, and $\mathbf{3 c}$ were deposited with the Cambridge Crystallographic Data Center as supplementary publication no. 1895410 (2a), 1850856 (2b), 1562677 (3a), 1562678 (3b) and $1562679(3 \mathrm{c}) \cdot \dagger$

\section{Epoxidation of cyclooctene}

A Heidolph Parallel Synthesizer 1 was used for all epoxidation experiments. In a typical experiment, 2-3 $\mathrm{mg}$ of catalyst ( $1 \mathrm{~mol} \%$ ) were dissolved in $0.5 \mathrm{~mL} \mathrm{CHCl}_{3}$ and mixed with cyclooctene ( 1 equiv.) and $50 \mu \mathrm{L}$ of mesitylene (internal standard) and heated to the respective reaction temperature $\left(50{ }^{\circ} \mathrm{C}\right)$. Then the oxidant ( 3 equiv.) was added. Aliquots for GC-MS $(20 \mu \mathrm{L})$ were withdrawn at given time intervals, quenched with $\mathrm{MnO}_{2}$ and diluted with HPLC grade ethyl acetate. The reaction products were analysed by GC-MS (Agilent 7890 A with an Agilent 19091J-433 column coupled to a mass spectrometer type Agilent $5975 \mathrm{C}$ ), and the epoxide produced from each reaction mixture was quantified $v s$. mesitylene as the internal standard. Experimental error of GC-MS measurements is $\pm 5 \%$.

\section{Synthesis of complex $\left(\mathrm{NBu}_{4}\right)\left[\operatorname{ReOCl}_{3}(\mathrm{L1a})\right] 2 \mathrm{a}$}

Ligand HL1a (0.030 g, $0.16 \mathrm{mmol}, 1$ equiv.) and $\left(\mathrm{NBu}_{4}\right)$ $\left[\mathrm{ReOCl}_{4}\right]$ (0.10 g, $0.16 \mathrm{mmol}, 1$ equiv.) were dissolved in $20 \mathrm{ml}$ EtOH and stirred at rt for $1 \mathrm{~h}$. The mixture turns green within 5 minutes. After $1 \mathrm{~h}$, a small amount of white precipitate (probably $\mathrm{NBu}_{4} \mathrm{Cl}$ ) is filtered off and the solvent removed completely. The crude product is a mixture of $\mathbf{2 a}$ and bis-ligated 3a, which can be separated by dissolving the better soluble $\mathbf{3 a}$ in small amounts of EtOAc, leaving behind analytical pure yellowish-greenish 2a (62 mg, 52\%). Recrystallization from EtOH/EtOAc (1/1 vol\%) yielded 2a as single crystals. ${ }^{1} \mathrm{H}$ NMR (300 MHz, chloroform-d) $\delta 7.61$ (dd, $J=7.9,1.8 \mathrm{~Hz}, 1 \mathrm{H}$ ), 7.12 (ddd, $J=8.7,7.1,1.8 \mathrm{~Hz}, 1 \mathrm{H}), 7.00-6.90$ (m, 1H), 6.90 (ddd, $J=$ 8.2, 7.1, $1.2 \mathrm{~Hz}, 1 \mathrm{H}), 4.51(\mathrm{~s}, 2 \mathrm{H}), 3.35-3.23(\mathrm{~m}, 8 \mathrm{H}), 1.74$ (s, 6H), 1.72-1.61 (m, 8H), 1.53-1.38 (m, 8H), $1.00(\mathrm{t}, J=7.3$ $\mathrm{Hz}, 12 \mathrm{H}) .{ }^{13} \mathrm{C}$ NMR (75 MHz, chloroform-d) $\delta 136.33,131.32$, 118.80, 116.96, 108.59, $78.98\left(\mathrm{CH}_{2}\right), 73.54,59.41\left(\mathrm{NBu}_{4}{ }^{+}\right), 26.78$ $\left(\mathrm{Me}_{2}\right), 24.39\left(\mathrm{NBu}_{4}^{+}\right), 19.95\left(\mathrm{NBu}_{4}^{+}\right), 13.90\left(\mathrm{NBu}_{4}^{+}\right)$, (two C obscured); ATR-IR $\nu_{\max } / \mathrm{cm}^{-1}$ : 2960, 2930, 2871, $1612(\mathrm{C}=\mathrm{N})$, 1482, 1378, 1323, 1271, 1082, 962 and $955(\mathrm{Re}=\mathrm{O}), 879,860$, 756, 616; EI-MS (m/z): $497.9\left(\mathrm{M}^{+}-\mathrm{NBu}_{4}\right)$; UV $\lambda_{\max }\left(\mathrm{CH}_{2} \mathrm{Cl}_{2}\right) / \mathrm{nm}$ : $710\left(\varepsilon / \mathrm{dm}^{3} \mathrm{~mol}^{-1} \mathrm{~cm}^{-1} 73\right)$; elemental analysis calculated for $\mathrm{C}_{27} \mathrm{H}_{48} \mathrm{Cl}_{3} \mathrm{~N}_{2} \mathrm{O}_{4} \mathrm{Re}\left(741.3 \mathrm{~g} \mathrm{~mol}^{-1}\right)$ : C 43.75, H 6.53, N 3.78; found $\mathrm{C} 42.83,6.51 \mathrm{H}, 3.30 \mathrm{~N}$.

\section{Synthesis of complex $\left(\mathrm{NBu}_{4}\right)\left[\operatorname{ReOCl}_{3}(\mathrm{~L} 1 \mathrm{~b})\right] 2 \mathrm{~b}$}

Ligand HL1b (0.083 g, 0.375 mmol, 1.1 equiv.) and $\left(\mathrm{NBu}_{4}\right)\left[\mathrm{ReOCl}_{4}\right](0.20 \mathrm{~g}, 0.34 \mathrm{mmol}, 1$ equiv.) were dissolved in $\mathrm{EtOH}$ and stirred at $\mathrm{rt}$ for $0.5 \mathrm{~h}$. An intense green color formed moments after dissolution. Upon concentration unreacted 
$\left(\mathrm{NBu}_{4}\right)\left[\mathrm{ReOCl}_{4}\right]$ precipitated and was removed by filtration. Removal of solvent yielded crude $\mathbf{2 b}$. Recrystallization from EtOH/EtOAc (1/1 vol\%) yielded $2 \mathbf{b}$ as single crystals (105 mg, 42\%). ${ }^{1} \mathrm{H}$ NMR $\left(300 \mathrm{MHz}, \mathrm{CDCl}_{3}\right) \delta 7.30$ (dd, $J=5.6,4.1 \mathrm{~Hz}$, $1 \mathrm{H}), 6.81-6.77(\mathrm{~m}, 2 \mathrm{H}), 4.51(\mathrm{~s}, 2 \mathrm{H}), 3.83(\mathrm{~s}, 3 \mathrm{H}), 3.26-3.15$ $(\mathrm{m}, 8 \mathrm{H}), 1.74(\mathrm{~s}, 6 \mathrm{H}), 1.65-1.52(\mathrm{~m}, 8 \mathrm{H}), 1.37(\mathrm{~m}, 8 \mathrm{H}), 0.95(\mathrm{t}$, $J=7.3 \mathrm{~Hz}, 12 \mathrm{H}) ;{ }^{13} \mathrm{C} \mathrm{NMR}\left(75 \mathrm{MHz}, \mathrm{CDCl}_{3}\right) \delta 166.53,157.48$, 148.69, 124.86, 123.98, 116.77, 109.78, 100.11, $78.91\left(\mathrm{CH}_{2}\right)$, 73.66, $59.54\left(\mathrm{OCH}_{3}\right), 58.83\left(\mathrm{NBu}_{4}^{+}\right), 26.81\left(\mathrm{Me}_{2}\right), 24.25\left(\mathrm{NBu}_{4}^{+}\right)$, $19.83\left(\mathrm{NBu}_{4}^{+}\right), 13.89\left(\mathrm{NBu}_{4}^{+}\right) ;$ATR-IR $\nu_{\max } / \mathrm{cm}^{-1}: \quad 2959$, 2933, $1609(\mathrm{C}=\mathrm{N}), 1582,1458,1379,1254,1055$, 969 and $957(\mathrm{Re}=\mathrm{O}), 845,737,670,567,435$; EI-MS $(\mathrm{m} / \mathrm{z}): 528.1$ $\left(\mathrm{M}^{+}-\mathrm{NBu}_{4}\right)$; UV $\lambda_{\max }\left(\mathrm{CH}_{2} \mathrm{Cl}_{2}\right) / \mathrm{nm}: 580\left(\varepsilon / \mathrm{dm}^{3} \mathrm{~mol}^{-1} \mathrm{~cm}^{-1} 56\right)$; elemental analysis calculated for $\mathrm{C}_{28} \mathrm{H}_{50} \mathrm{Cl}_{3} \mathrm{~N}_{2} \mathrm{O}_{4} \operatorname{Re}\left(771.3 \mathrm{~g} \mathrm{~mol}^{-1}\right)$ : C 43.60, H 6.53, N 3.63; found C 43.78, H 6.48, N 3.66.

UV-Vis data of complex 3a. UV $\lambda_{\max }\left(\mathrm{CH}_{2} \mathrm{Cl}_{2}\right) / \mathrm{nm}: \quad 650$ $\left(\varepsilon / \mathrm{dm}^{3} \mathrm{~mol}^{-1} \mathrm{~cm}^{-1} 70\right)$; other analytical data has been previously published. ${ }^{12}$

\section{Synthesis of complex $\left[\operatorname{ReOCl}(\operatorname{L1b})_{2}\right] 3 b$}

Ligand HL1b (0.63 g, $2.85 \mathrm{mmol}, 2$ equiv.) and precursor $\left[\mathrm{ReOCl}_{3}\left(\mathrm{OPPh}_{3}\right)\left(\mathrm{SMe}_{2}\right)\right](0.93 \mathrm{~g}, 1.43 \mathrm{mmol}, 1$ equiv.) was heated under reflux in $30 \mathrm{ml} \mathrm{CH}_{3} \mathrm{CN}$ for $3 \mathrm{~h}$. Analytically pure 3b precipitated upon cooling and was isolated by filtration (495 mg, 51\%). Single crystals suitable for X-ray diffraction analysis were obtained from EtOH/EtOAc. ${ }^{1} \mathrm{H}$ NMR $(300 \mathrm{MHz}$, chloroform-d) $\delta 7.53$ (dd, $J=8.3,1.6 \mathrm{~Hz}, 1 \mathrm{H}), 7.34(\mathrm{dd}, J=8.0$, $1.6 \mathrm{~Hz}, 1 \mathrm{H}), 6.92-6.82(\mathrm{~m}, 2 \mathrm{H}), 6.76(\mathrm{dd}, J=8.0,1.6 \mathrm{~Hz}, 1 \mathrm{H})$, $6.67(\mathrm{t}, J=8.1 \mathrm{~Hz}, 1 \mathrm{H}), 4.67-4.51(\mathrm{~m}, 4 \mathrm{H}), 3.73(\mathrm{~s}, 3 \mathrm{H}), 3.67(\mathrm{~s}$, 3H), 2.00 (s, 3H), $1.90(\mathrm{~s}, 6 \mathrm{H}), 1.64(\mathrm{~s}, 3 \mathrm{H}) ;{ }^{13} \mathrm{C}$ NMR (75 MHz, $\left.\mathrm{CDCl}_{3}\right) \delta 150.22,121.98,121.33,118.65,117.54,116.48,115.70$, 110.92, 81.89, 79.47, 78.75, 72.92, $55.86\left(\mathrm{OCH}_{3}\right), 55.43\left(\mathrm{OCH}_{3}\right)$, 27.61, 27.10, 27.07, 25.97 (some C are obscured); ATR-IR $\nu_{\max } / \mathrm{cm}^{-1}: 1582(\mathrm{~s}, \mathrm{C}=\mathrm{N}), 1379(\mathrm{~s}), 1052(\mathrm{~m}), 955(\mathrm{~s}, \mathrm{Re}=\mathrm{O})$; EI-MS $\quad(\mathrm{m} / \mathrm{z}): \quad 678.2 \quad\left(\mathrm{M}^{+}\right) ; \quad$ UV $\quad \lambda_{\max }\left(\mathrm{CH}_{2} \mathrm{Cl}_{2}\right) / \mathrm{nm}: \quad 660$ $\left(\varepsilon / \mathrm{dm}^{3} \mathrm{~mol}^{-1} \mathrm{~cm}^{-1} 65\right)$; elemental analysis calculated for $\mathrm{C}_{24} \mathrm{H}_{28} \mathrm{ClN}_{2} \mathrm{O}_{7} \mathrm{Re}\left(678.15 \mathrm{~g} \mathrm{~mol}^{-1}\right)$ : $\mathrm{C}$ 42.51, $\mathrm{H}$ 4.16, N 4.13; found C 42.74, H 4.06, N 4.08.

\section{Synthesis of complex $\left[\operatorname{ReOCl}(\mathrm{L} 1 \mathrm{c})_{2}\right] 3 \mathrm{c}$}

Ligand HL1c (0.50 g, $2.12 \mathrm{mmol}, 2$ equiv.) and precursor $\left[\mathrm{ReOCl}_{3}\left(\mathrm{OPPh}_{3}\right)\left(\mathrm{SMe}_{2}\right)\right]$ (0.69 g, $1.06 \mathrm{mmol}, 1$ equiv.) was heated under reflux in $30 \mathrm{ml} \mathrm{CH}_{3} \mathrm{CN}$ for $4 \mathrm{~h}$. Analytically pure 3c precipitated upon cooling and was isolated by filtration (375 mg, 50\%). Single crystals suitable for X-ray diffraction analysis were obtained from DCM/heptane. ${ }^{1} \mathrm{H} \quad \mathrm{NMR}$ $\left(300 \mathrm{MHz}, \mathrm{CDCl}_{3}\right) \delta 8.98(\mathrm{~d}, J=2.8 \mathrm{~Hz}, 1 \mathrm{H}), 8.72(\mathrm{~d}, J=2.9 \mathrm{~Hz}$, $1 \mathrm{H}), 8.24(\mathrm{dd}, J=9.3,2.9 \mathrm{~Hz}, 1 \mathrm{H}), 8.07(\mathrm{dd}, J=9.2,2.9 \mathrm{~Hz}, 1 \mathrm{H})$, $6.90(\mathrm{~d}, J=9.4 \mathrm{~Hz}, 2 \mathrm{H}), 6.74(\mathrm{~d}, J=9.2 \mathrm{~Hz}, 1 \mathrm{H}), 4.79(\mathrm{dd}, J=$ 8.5, $4.1 \mathrm{~Hz}, 2 \mathrm{H}), 4.70$ (d, $J=8.5 \mathrm{~Hz}, 1 \mathrm{H}), 4.60(\mathrm{~d}, J=8.5 \mathrm{~Hz}$, $1 \mathrm{H}), 1.96(\mathrm{~s}, 3 \mathrm{H}), 1.95(\mathrm{~s}, 3 \mathrm{H}), 1.84(\mathrm{~s}, 3 \mathrm{H}), 1.67(\mathrm{~s}, 3 \mathrm{H})$; because of the low solubility of $3 \mathrm{c}$ no meaningful ${ }^{13} \mathrm{C} \mathrm{NMR}$ spectra could be acquired; HSQC $\left(\mathrm{CDCl}_{3}\right) \delta 131.05,130.26$, 128.19, 128.01, 122.44, 119.35, 82.40, 82.24, 79.67, 79.62, 27.15, 27.13, 27.10, 25.86; ATR-IR $\nu_{\max } / \mathrm{cm}^{-1}: 1611,1588$ (s, $\mathrm{C}=\mathrm{N}), 1312,1269\left(\mathrm{~s}, \mathrm{NO}_{2}\right), 963(\mathrm{~s}, \mathrm{Re}=\mathrm{O})$; EI-MS $(\mathrm{m} / \mathrm{z}): 708.3$
$\left(\mathrm{M}^{+}\right) ; \quad \mathrm{UV} \quad \lambda_{\max }\left(\mathrm{CH}_{2} \mathrm{Cl}_{2}\right) / \mathrm{nm}: 670\left(\varepsilon / \mathrm{dm}^{3} \quad \mathrm{~mol}^{-1} \quad \mathrm{~cm}^{-1} \quad 85\right)$; elemental analysis calculated for $\mathrm{C}_{22} \mathrm{H}_{22} \mathrm{ClN}_{4} \mathrm{O}_{9} \mathrm{Re} \cdot 0.5 \mathrm{CH}_{2} \mathrm{Cl}_{2}$ (708.06 $\mathrm{g} \mathrm{mol}^{-1}$ ): C 36.00, H 3.09; N 7.46; found C 36.01; H 2.98; N 7.00.

\section{Conflicts of interest}

There are no conflicts to declare.

\section{Acknowledgements}

The organizers of the $7^{\text {th }}$ EuCheMS conference on N-ligands in September 2018, Lisbon, where parts of this research was presented, are thankfully acknowledged. Financial support from NAWI Graz is gratefully acknowledged.

\section{Notes and references}

1 (a) W. A. Herrmann, R. W. Fischer and D. W. Marz, Angew. Chem., Int. Ed. Engl., 1991, 30, 1638-1641; (b) W. A. Herrmann and M. Wang, Angew. Chem., Int. Ed. Engl., 1991, 30, 1641-1643.

2 (a) R. G. Harms, W. A. Herrmann and F. E. Kühn, Coord. Chem. Rev., 2015, 296, 1-23; (b) J. Rudolph, K. L. Reddy, J. P. Chiang and K. B. Sharpless, J. Am. Chem. Soc., 1997, 119, 6189-6190; (c) C. Copéret, H. Adolfsson and K. Barry Sharpless, Chem. Commun., 1997, 1565-1566; (d) C. C. Romão, F. E. Kühn and W. A. Herrmann, Chem. Rev., 1997, 97, 3197-3246.

3 S. Huber, M. Cokoja and F. E. Kühn, J. Organomet. Chem., 2014, 751, 25-32.

4 F. E. Kühn, A. Scherbaum and W. A. Herrmann, J. Organomet. Chem., 2004, 689, 4149-4164.

5 W. A. Herrmann, J. Organomet. Chem., 1995, 500, 149-173.

6 J. W. Kück, R. M. Reich and F. E. Kühn, Chem. Rec., 2016, 16, 349-364.

7 S. Yamazaki, Org. Biomol. Chem., 2007, 5, 2109-2113.

8 (a) W. Adam and C. M. Mitchell, Angew. Chem., Int. Ed. Engl., 1996, 35, 533-535; (b) T. R. Boehlow and C. D. Spilling, Tetrahedron Lett., 1996, 37, 2717-2720; (c) P. Altmann, M. Cokoja and F. E. Kühn, Eur. J. Inorg. Chem., 2012, 2012, 3235-3239.

9 W. A. Herrmann, M. U. Rauch and G. R. J. Artus, Inorg. Chem., 1996, 35, 1988-1991.

10 F. E. Kühn, M. U. Rauch, G. M. Lobmaier, G. R. J. Artus and W. A. Herrmann, Chem. Ber., 1997, 130, 1427-1431.

11 N. Zwettler, J. A. Schachner, F. Belaj and N. C. MöschZanetti, Inorg. Chem., 2016, 55, 5973-5982.

12 J. A. Schachner, B. Terfassa, L. M. Peschel, N. Zwettler, F. Belaj, P. Cias, G. Gescheidt and N. C. Mösch-Zanetti, Inorg. Chem., 2014, 53, 12918-12928.

13 (a) B. Terfassa, J. A. Schachner, P. Traar, F. Belaj and N. C. Mösch-Zanetti, Polyhedron, 2014, 75, 141-145; (b) B. Machura, M. Wolff, D. Tabak, J. A. Schachner and 
N. C. Mösch-Zanetti, Eur. J. Inorg. Chem., 2012, 3764-3773; (c) S. Dinda, M. G. B. Drew and R. Bhattacharyya, Catal. Commun., 2009, 10, 720-724.

14 N. Zwettler, J. A. Schachner, F. Belaj and N. C. MöschZanetti, Inorg. Chem., 2014, 53, 12832-12840.

15 B. Machura, M. Wolff, E. Benoist, J. A. Schachner and N. C. Mösch-Zanetti, Dalton Trans., 2013, 42, 8827-8837.

16 P. Traar, J. A. Schachner, L. Steiner, A. Sachse, M. Volpe and N. C. Mösch-Zanetti, Inorg. Chem., 2011, 50, 19831990.

17 B. Machura, M. Wolff and I. Gryca, Coord. Chem. Rev., 2014, 275, 154-164.

18 F. E. Kühn, A. M. Santos and W. A. Herrmann, Dalton Trans., 2005, 34, 2483-2491.

19 W. A. Herrmann, R. W. Fischer, M. U. Rauch and W. Scherer, J. Mol. Catal., 1994, 86, 243-266.

20 (a) L. F. Veiros, A. Prazeres, P. J. Costa, C. C. Romão, F. E. Kühn and M. J. Calhorda, Dalton Trans., 2006, 13831389; (b) J. Morlot, N. Uyttebroeck, D. Agustin and R. Poli, ChemCatChem, 2013, 5, 601-611; (c) M. E. Judmaier, C. Holzer, M. Volpe and N. C. Mösch-Zanetti, Inorg. Chem., 2012, 51, 9956-9966.

21 J. R. Winkler and H. B. Gray, in Molecular electronic structures of transition metal complexes, ed. D. M. P. Mingos, J. P. Dahl and M. Atanasov, Springer, Berlin, 2012, pp. 17-28.

22 M. M. Abu-Omar, L. D. McPherson, J. Arias and V. M. Béreau, Angew. Chem., Int. Ed., 2000, 39, 4310-4313.

23 J. Arias, C. R. Newlands and M. M. Abu-Omar, Inorg. Chem., 2001, 40, 2185-2192.

24 L. D. McPherson, M. Drees, S. I. Khan, T. Strassner and M. M. Abu-Omar, Inorg. Chem., 2004, 43, 4036-4050.

25 M. M. Abu-Omar, Comments Inorg. Chem., 2003, 24, 15-37.

26 J. Liu, D. Wu, X. Su, M. Han, S. Y. Kimura, D. L. Gray, J. R. Shapley, M. M. Abu-Omar, C. J. Werth and T. J. Strathmann, Inorg. Chem., 2016, 55, 2597-2611.
27 J. Liu, X. Su, M. Han, D. Wu, D. L. Gray, J. R. Shapley, C. J. Werth and T. J. Strathmann, Inorg. Chem., 2017, 56, 1757-1769.

28 H. C. Aspinall, O. Beckingham, M. D. Farrar, N. Greeves and C. D. Thomas, Tetrahedron Lett., 2011, 52, 5120-5123.

29 P. G. Cozzi, C. Floriani, A. Chiesi-Villa and C. Rizzoli, Inorg. Chem., 1995, 34, 2921-2930.

30 M. Hoogenraad, K. Ramkisoensing, S. Gorter, W. L. Driessen, E. Bouwman, J. G. Haasnoot, J. Reedijk, T. Mahabiersing and F. Hartl, Eur. J. Inorg. Chem., 2002, 377-387.

31 G. M. Lobmaier, G. D. Frey, R. D. Dewhurst, E. Herdtweck and W. A. Herrmann, Organometallics, 2007, 26, 6290-6299.

32 (a) S. Gatto, T. I. A. Gerber, G. Bandoli, J. Perils and J. G. H. Du Preez, Inorg. Chim. Acta, 1998, 269, 235-240; (b) C. Bolzati, F. Tisato, F. Refosco, G. Bandoli and A. Dolmella, Inorg. Chem., 1996, 35, 6221-6229; (c) S. M. Harben, P. D. Smith, R. L. Beddoes, D. Collison and C. D. Garner, J. Chem. Soc., Dalton Trans., 1997, 27772784; (d) H. Luo, S. J. Rettig and C. Orvig, Inorg. Chem., 1993, 32, 4491-4497; (e) M. Shivakumar, S. Banerjee, M. Menon and A. Chakravorty, Inorg. Chim. Acta, 1998, 275-276, 546-551; (f) J. D. G. Correia, Â. Domingos, I. Santos, C. Bolzati, F. Refosco and F. Tisato, Inorg. Chim. Acta, 2001, 315, 213-219; (g) E. J. de Souza, V. M. Deflon, A. G. de, A. Fernandes, S. S. Lemos, A. Hagenbach and U. Abram, Inorg. Chim. Acta, 2006, 359, 1513-1518.

33 A. Sachse, N. C. Mösch-Zanetti, G. Lyashenko, J. W. Wielandt, K. Most, J. Magull, F. Dall'Antonia, A. Pal and R. Herbst-Irmer, Inorg. Chem., 2007, 46, 7129-7135.

34 C. C. van Kirk, V. M. Béreau, M. M. Abu-Omar and D. H. Evans, J. Electroanal. Chem., 2003, 541, 31-38.

35 B. D. Sherry, R. N. Loy and F. D. Toste, J. Am. Chem. Soc., 2004, 126, 4510-4511.

36 R. Alberto, R. Schibli, A. Egli, P. August Schubiger, W. A. Herrmann, G. R. J. Artus, U. Abram and T. A. Kaden, J. Organomet. Chem., 1995, 493, 119-127. 